УДК 378.147

DOI:

Юлія Мельничук, кандидат педагогічних наук, старший викладач кафедри комп'ютерних наук

Луцького національного технічного університету

Юрій Сачук, кандидат фізико-математичних наук, старший викладач, завідувач кафедри комп'ютерних наук та кібербезпеки

Східноєвропейського національного університету

Іванна Саланда, кандидат технічних наук, доцент кафедри теорії і методики трудового навчання та технологій Кременецької обласної гуманітарно-педагогічної академії імені Тараса Шевченка

\title{
РОЗРОБКА ТА ВПРОВАДЖЕННЯ У НАВЧАЛЬНИЙ ПРОЦЕС ЗЗСО ВЕБ-ПОРТАЛУ ДЛЯ ВИВЧЕННЯ ІНФОРМАТИКИ
}

Стаття присвячена розгляду питання розробки та наступного впровадження веб-порталу для вивчення інформатики школярами 3ЗСО. Здійснено огляд предметної галузі дослідження, проаналізовано можслиості та структуру освітніх порталів. Обтрунтовано вибір платформи розробки веб-ресурсу; деталізований процес проєктування інформаційної системи; запропонована структурно-функційна схема об' 'кта проектування. Здійснено детальний опис кожного з блоків ресурсу та їх функиіонал. Веб-портал впроваджено в освітній прочес та окреслено перспективи подальших наукових розвідок у вибраному руслі.

Ключові слова: освітній веб-портал; освітній процес; інформатика; система управління контентом. Puc. 2. Лim. 7.

Juliya Melnychuk, Ph.D.(Pedagogy), Senior Lecturer of the Computer Science Department Lutsk National Technical University Yuriy Sachuk, Ph.D.(Physical and Mathematical Sciences), Senior Lecturer, Head of the Computer Science and Cybersecurity Department

Eastern European National University

Ivanna Salanda, Ph.D.(Technical Sciences), Associate Professor of the Theory and Methods of Labor Training and Technology Department Kremenets Regional Humanitarian and Pedagogical Academy named after Taras Shevchenko

\section{DEVELOPMENT AND IMPLEMENTATION IN THE LEARNING PROCESS OF GSEI WEB-PORTAL FOR THE STUDY OF INFORMATICS}

The article is devoted to the issue of development and subsequent implementation of a web portal for the study of computer science by students of GSEI. It was done overview of the subject area of research, an analysis of capabilities and structure of educational portals. There is a process of gaining experience, finding ways to improve the quality of education and new forms of using information and communication technologies in various educational processes. An analysis of similar research in this regard shows that software products that meet such needs can be developed on the basis of web technologies. Web technologies have a number of advantages for the realization of educational needs of students and teachers. The purpose of this article is to design and develop a web portal for the study of computer science in the 9th grade GSEI on the basis of CMS WordPress. The choice of web resource development platform is substantiated; detailed information system design process; proposed structural and functional scheme of the design object. The integration of scientific and educational resources in the portal allows simplifying administration and making resources more accessible. The purpose of building such an environment is to provide wider access to scientific and educational information compared to traditional technologies of scientific and pedagogical communication. A detailed description of each of the resource blocks and their functionality was made. The web portal is introduced into the educational process and outlines the prospects for further scientific research in the chosen direction. We see the prospect of further research in the current direction in expanding the functions of the educational web portal for studying computer science in the 9th grade of GSEI, in particular, the possibility of organizing an internal forum, video communication between students and teachers, cooperation with larger educational web portals.

Keywords: an educational web portal; an educational process; computer science; content management system.

3

агальна постановка проблеми. Актуальність дослідження базується на

Інтернет-технологій у сучасній шкільній освіті. активізації процесу використання

Цей процес ставить низку гострих проблем, що $€$ предметом обговорення вчених, учителів, 


\section{РОЗРОБКА ТА ВПРОВАДЖЕННЯ У НАВЧАЛЬНИЙ ПРОЦЕС ЗЗСО ВЕБ-ПОРТАЛУ ДЛЯ ВИВЧЕННЯ ІНФОРМАТИКИ}

працівників освіти, які пов'язують розвиток середньої освіти із активним використанням Інтернет-технологій, створенням єдиного освітнього простору, що сприяє розвитку та самореалізації учнів.

Сучасний етап застосування Інтернету в середній освіті можна вважати експериментальним. Відбувається процес нагромадження досвіду, пошуку шляхів підвищення якості навчання та нових форм використання інформаційнокомунікаційних технологій (ІКТ) у різноманітних освітніх процесах. Труднощі в оволодінні ІКТ в освіті виникають через відсутність не тільки методичної бази їх використання в обраній сфері, але й методології розробки адаптованих до освітнього процесу програмно-технічних засобів навчання, що змушує педагога на практиці орієнтуватися лише на власний досвід та уміння шукати шляхи ефективного застосування інформаційних технологій.

Аналіз схожих досліджень у цьому руслі показує, що програмні продукти, які задовольняють такі потреби, можуть бути розроблені на основі веб-технологій. Саме вони володіють низкою переваг для реалізації освітніх потреб учнів та педагогів:

- інтерактивний характер комунікації;

- доступність інформації протягом усієї доби користувачам цілого світу;

- оперативне поновлення інформації, іiі доповнення із врахуванням запитань чи пропозицій відвідувачів сайту;

- надання необмеженого об'єму інформації, у тому числі мультимедійної;

- формування привабливого образу закладу загальної середньої освіти;

- персоналізація інформації, призначеної для різноманітних цільових груп;

- багатоаспектний та швидкий пошук необхідних відомостей у великих масивах інформації;

- отримання відомостей щодо відвідуваності сайту, тобто його результативності як засобу комунікації.

Зазначені переваги набуваються веб-сайтами у результаті обдуманого та обгрунтованого підходу до їх створення.

Аналіз основних досліджень і публікацій. Існує чимало наукових праць у ракурсі використання інформаційних технологій у школі, зокрема, під час вивчення інформатики. Проте як найновіші з них розглядалися дослідження I. Василиківа [1], О. Шаран [7], О. Мойко [4], Я. Донченко [2] та ін.

Метою пропонованої статті $є$ проектування та розробка веб-порталу для вивчення інформатики у 9 класі $33 \mathrm{CO}$ на базі CMS WordPress.

Виклад основного матеріалу. Портал мережевий вузол чи комплекс вузлів, підключених до мережі Інтернет по високошвидкісних каналах зв'язку, що характеризується розвинутим користувацьким інтерфейсом та наданням єдиному 3 концептуальної та змістової точок зору доступу до широкого спектру інформаційних ресурсів та послуг, орієнтованих на визначену аудиторію.

Освітні портали мають свою специфіку, оскільки їхні сутність, структура та функції порталів визначаються цілями освіти. Основна мета освітнього порталу - організація різних суб'єктів освіти, дає їм змогу здійснити безпосередній освітній процес, надати необхідну інформацію, створити необхідні засоби комунікації у мережі Інтернет та ін. Сьогодні більшість закладів освіти мають власні портали, що не тільки дають уявлення про їхню діяльність, структуру та характер, а й організовують простір наукової комунікації. Інформативна функція порталів значно розширює можливості наукової, освітньої та соціальної діяльності освітніх закладів.

Інтеграція науково-освітніх ресурсів у порталі допомагає спростити адміністрування та зробити ресурси доступнішими. Метою побудови такого середовища є забезпечення широкого доступу до наукової та освітньої інформації порівняно із традиційними технологіями наукового та педагогічного спілкування. Це можна реалізувати, прямуючи за визначеними принципами надання доступу до інформації.

Узагальнивши міркування, визначили поняття освітнього порталу із технологічної точки зору як системного об'єднання освітніх ресурсів, що працюють на основі єдиної бази даних та єдиних стандартів обміну інформацією; із смислової точки зору - це навчально-методичний центр. Цим власне визначається пріоритет контенту вебресурсу над технологією, яка розглядається як інструментальний засіб у дослідженні.

Зважаючи на мету дослідження, нами універсальним для створення галузевого освітнього середовища було прийнято рішення розробити освітній портал, на базі якого можуть розв'язуватися два ключові завдання [3]:

- об’єднання інформаційних та освітніх ресурсів галузі, що презентують різноманітні інформаційні, технологічні, довідкові й освітні функції в єдиному інформаційно-освітньому середовищі;

- побудова інтерфейсної надбудови над даним середовищем, що забезпечує структурований доступ до її ресурсів для користувачів.

Для побудови освітнього порталу питання 
вибору правильної надійної платформи є ключовим. Обгрунтований вибір здійснювався шляхом порівняльного аналізу різних варіантів. Системою у цьому випадку є комплекс вимог, що включає як загальні, так і спеціальні (функціональні, архітектурні, програмні, апаратні) вимоги до програмно-технологічних платформ. Базою розробки було обрано CMS WordPress.

Донедавна веб-сайти, що базуються на CMS, були останнім нововведенням у мережі. Багато великих компаній застосовували CMS для своїх сайтів, оскільки вони дають змогу управляти контентом, не знаючи тонкощів мови HTML. WordPress $\epsilon$ безкоштовним програмним забезпеченням з відкритим вихідним кодом, яке можна завантажити і встановити за кілька хвилин. Крім того, модулі і теми розширюють закладені в платформу можливості [5].

Система управління контентом WordPress не вимагає особливих заходів щодо оптимізації і підвищення продуктивності, хоча можлива зміна деяких налаштувань, які оптимально пристосують дану CMS під потреби веб-ресурсу.

Для реалізації освітнього веб-порталу на обраній платформі перед нами постало завдання проєктування ресурсу та побудови структурнофункціональної схеми.

Функціональна схема або схема даних - це схема взаємодії компонентів програмного забезпечення з описом інформаційних потоків, складу даних у потоках та вказанням використовуваних файлів та пристроїв. Функціональні схеми більш інформативні, ніж структурні. Усі компоненти структурних та функціональних схем повинні бути описані [6].

Для побудови функціональної схеми відштовхнемось від цілі та основних функцій розроблюваного програмного забезпечення.

Мета створення веб-порталу-розробка нових стандартів організації та інформаційного забезпечення освітнього процесу вивчення інформатики у 9 класі $33 \mathrm{CO}$.

Завдання розроблюваного веб-порталу для вивчення інформатики у 9 класі 33СО:

- забезпечення широкого та якісного доступу до наявних освітніх продуктів;

- навчально-методичний супровід освітнього процесу вивчення інформатики у 9 класі 33СО;

- розробка нових освітніх продуктів;

- просування модельних форм організації освітнього процесу;

- стимулювання процесу створення інноваційних освітніх продуктів.

Основні функції веб-порталу для вивчення інформатики у 9 класі $33 \mathrm{CO}$ такі.
Для учителів інформатики та тих хто бажають ними стати, поліпшити педагогічну майстерність: удосконалення традиційної методики навчання; використання інноваційних форм та методів навчання; здійснення культурнопросвітницької діяльності у галузі інформатики; пошук нормативної і методичної документації.

Для учнів: підготовка до занять; підготовка до позакласних заходів; підготовка до контролю знань; використання ресурсу для виконання навчальних завдань на уроках; діяльність під час дозвілля.

Для батьків: моніторинг виконання учнями домашніх завдань; підвищення власної ІКТ грамотності; діяльність на дозвіллі; можливість зворотного зв'язку із вчителем.

Принципи роботи порталу. Некомериійний принции - усі ресурси порталу є у відкритому та безоплатному доступі.

Професійний принцип - усі ресурси проходять через експертний відбір розробників та опрацювання;

Правовий принциип - усі ресурси порталу розміщені із збереженням авторських і суміжних прав.

Враховуючи вищезазначене, функціональна схема веб-порталу для вивчення інформатики у 9 класі 33СО, матиме такий вигляд (рис. 1).

Основними елементами(блоками) розроблюваного веб-ресурсу є "Головна", "На урок”, “Контроль знань", "Бібліотека" та "Про нас".

Елемент “Головна” містить вітальне слово, карту сайту, календар та форму із пропозицією підписки на оновлення сайту.

Елемент “На урок” вміщує 8 підпорядкованих веб-сторінок, що відображають теми наповнення курсу “Інформатика (9 клас)” із відповідними методичними розробками для проведення уроків.

Елемент “Контроль знань” відображає розроблені орієнтовні тестові завдання для проведення контролю знань із відповідних тем.

Елемент “Бібілотека” має у підпорядкуванні сторінки "Підручники”, “Календарне планування" та “Документація", що служать нормативною базою для проведення занять.

В елементі “Про нас" розміщені контактні дані про З3СО та форма для зворотного зв’язку.

Інтерфейс веб-ресурсу зображено на рис. 2. Для коректного відображення контенту розробленого освітнього веб-порталу можна використовувати будь-який браузер як леп-топу чи ПК, так і мобільних пристроїв.

Головна сторінка містить такі структурні елементи: шапка сайту, у якій розміщене меню назва; вітальне слово, форма підписки на новини веб-порталу; меню соціальних мереж. 


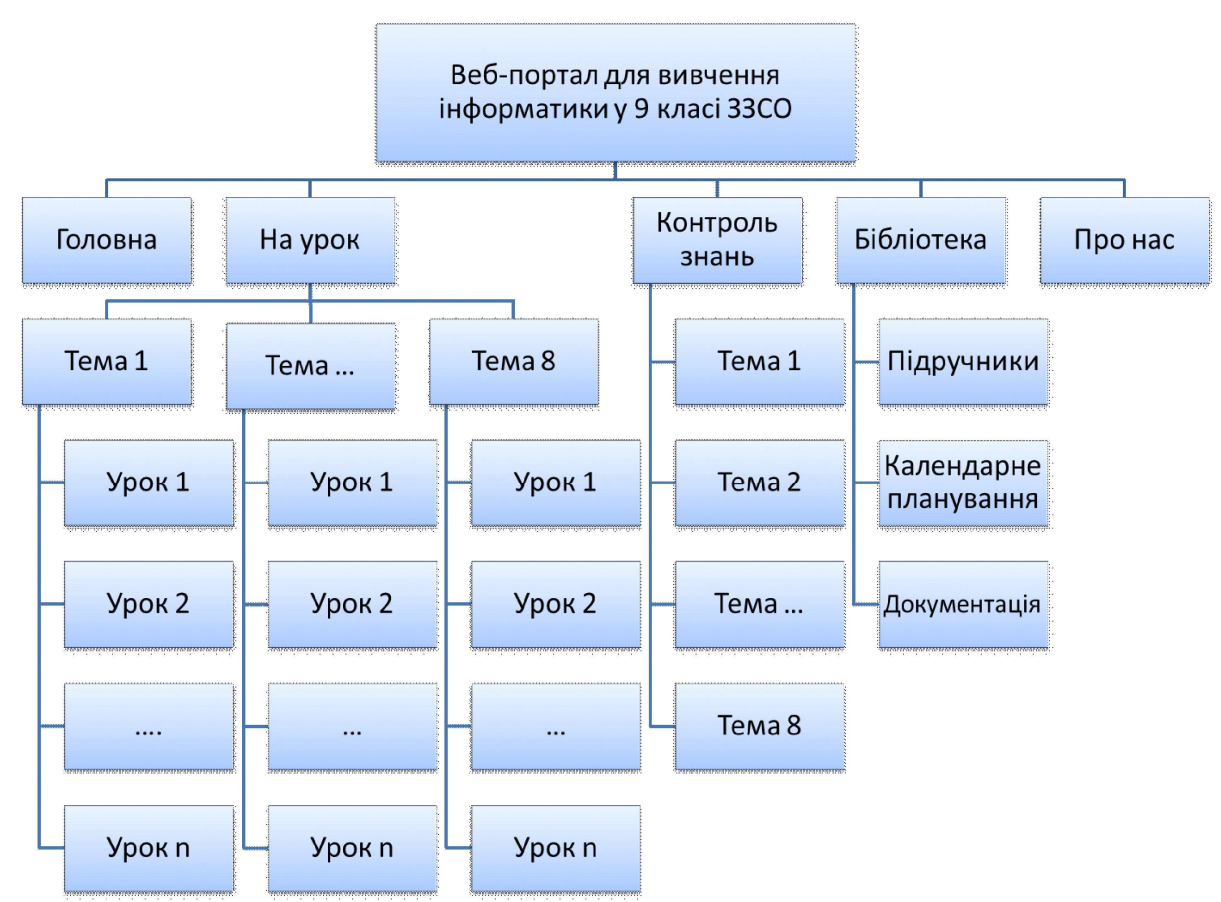

Рис.1. Структурно-функціональна схема веб-порталу для вивчення інформатики у 9 класі 33 СO

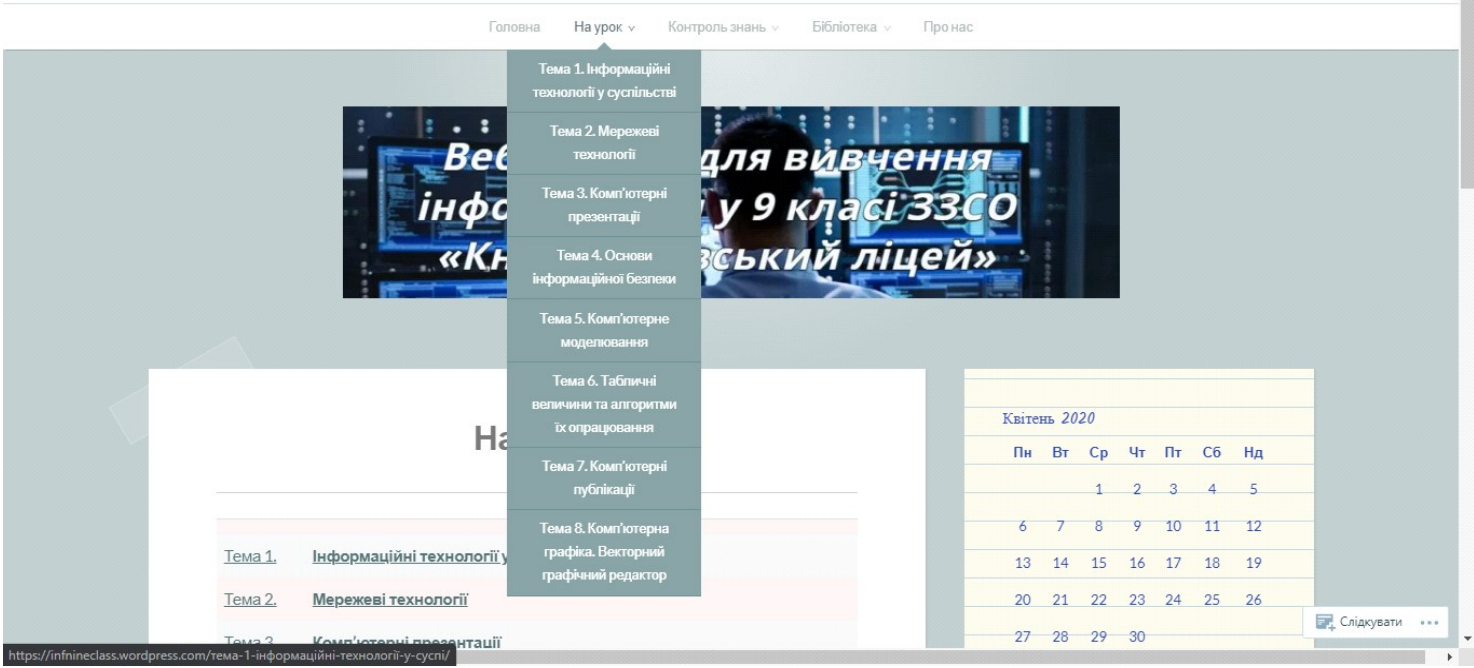

Рис. 2. Інтерфейс веб-порталу для вивчення інформатики у 9 класі $33 \mathrm{CO}$

Усі сторінки веб-порталу супроводжують календар та карта сайту, що розміщені у правій частині.

Веб-портал включає п’ять блоків: “Головна”, “На урок”, “Контроль знань”, "Бібліотека” та "Про нас". Деякі з блоків містять підпорядковані сторінки.

У блоці "На урок“ відображаються теми, що вивчаються у курсі “Інформатика (9 клас)". Перейшовши за посиланням необхідної теми, відкривається сторінка із переліком уроків, що до неї належать. Натиснувши на відповідний урок, переходимо до плану-конспекту його проведення.
Кожен із уроків супроводжується мультимедійною презентацією.

Блок “Контроль знань” містить розроблені тестові завдання по кожній із тем; можуть бути використані для проведення атестації дев'ятикласників, а також служать для підготовки учнів до контролю. Завдання для контролю розроблені у тестовій формі для двох варіантів.

У блоці "Бібліотека" розміщені сторінки “Підручники”, “Календарно-тематичне планування” та “Документація”, кожна з яких містить відповідні матеріали.

Висновки. Результатом проведеного 
дослідження став повноцінний освітній портал для вивчення інформатики у 9 класі ЗЗСО. Під час проведення дослідження поставлені завдання виконані у повному обсязі, досягнуто очікуваної мети. Зокрема:

- проаналізовано ланку наявних освітніх порталів, їх структуру, наведені базові дефініції щодо теми дослідження;

- наведено переваги застосування освітніх вебпорталів;

- здійснено вибір об'єкту проектування, визначено його структуру та функціональність;

- описано вибір інструменту для реалізації, його доцільність, наведено основні переваги;

- представлено створену розробку, очевидною $\epsilon$ необхідність їі використання в освітньому процесі 33СО.

Перспективу подальших досліджень у поточному руслі вбачаємо у розширенні функційності освітнього веб-порталу для вивчення інформатики у 9 класі 33СО, зокрема, можливості організації внутрішнього форуму, відеозв'язку між учнями та вчителем, співпраці із більш масштабними освітніми веб-порталами.

\section{ЛIТЕРАТУРА}

1. Василиків I. Застосування інформаційних технологій для розвитку творчого мислення учнів на уроках і в позакласній роботі в початковій школі. Молодь і ринок : щзомісяч. наук.-пед. журн. Дрогобич. 2019. № 10 (177). С. 69-74.

2. Донченко Я. Цілі шкільного курсу інформатики: ретроспективний аналіз. Молодь $i$ ринок : щомісяч. наук.-пед. журн. Дрогобич. ДДПУ, 2016. № 4. С. 157 - 161

3. Можаєва Г.В., Тубалова І.В. Як підготувати мультимедіа курс? Методичний посібник для викладачів / під ред. В. П. Дьомкіна. Томськ: ТГУ, 2012. $41 \mathrm{c}$.

4. Мойко О. Розвиток логічного мислення молодших школярів на уроках інформатики. Молодь і ринок. 2019. № 11. С. 31-36.

5. НОУ ИНТУИТ: Лекция. Системы управления контентом. URL: http:/www.intuit.ru/studies/courses/ 1036/239/lecture/6178 Дата обращения: 24.05.2020

6. Ташков П. А. Веб-мастеринг на $100 \%$ : HTML, CSS, JavaScript, PHP, CMS, AJAX, раскрутка. СПб.: Питер, 2010. 512 с.

7. Шаран О.В., Шаран В.Л. Методичні аспекти розвитку креативності молодших школярів на уроках інформатики за допомогою електронно- освітніх ресурсів. Молодь і ринок: щзомісячний науково-педагогічний журнал. Дрогобич. 2017. № 10 (153). C. 28 - 34 .

\section{REFERENCES}

1. Vasylykiv, I. (2019). Zastosuvannya informatsiynykh tekhnolohiy dlya rozvytku tvorchoho myslennya uchniv na urokakh i v pozaklasniy roboti v pochatkoviy shkoli [The use of information technology for the development of creative thinking of students in the classroom and in extracurricular activities in primary school]. "Youth and market". Monthly scientificpedagogical journal. Drogobych, Vol. 10 (177), pp. 69-74. [in Ukrainian].

2. Donchenko, J. (2016). Tsili shkilnoho kursu informatyky: retrospektyvnyy analiz. [Objectives of the school course of computer science: retrospective analysis]. "Youth and market". Monthly scientificpedagogical journal. Drogobych, Vol. 4, pp. 156161. [in Ukrainian].

3. Mozhaeva, G. \& Tubalova, I.V. (2012). Yak pidhotuvaty multymedia kurs? [How to prepare a multimedia course?]. Methodical manual for teachers, Tomsk: TSU, 41 p. [in Ukrainian].

4. Moiko, O. (2019). Rozvytok lohichnoho myslennya molodshykh shkolyariv na urokakh informatyky [Development of logical thinking of junior schoolchildren in computer science lessons]. "Youth and market". Monthly scientific-pedagogical journal. Drogobych, Vol. 11, pp. 31-36. [in Ukrainian].

5. KNOW INTUIT (2020): Lektsiya. Sistemy upravleniya kontentom [Lecture. Content management systems]. Available at: http:// www.intuit.ru/studies/courses/1036/239/lecture/6178 (Access 24 June 2020). [in Russian].

6. Tashkov, P.A. (2010). Veb-mastering na $100 \%$ : HTML, CSS, JavaScript, PHP, CMS, AJAX, raskrutka [Web mastering at 100\%: HTML, CSS, JavaScript, PHP, CMS, AJAX, promotion]. Saint Petersburg, 512 p. [in Russian].

7. Sharan, O.V. \& Sharan, V.L. (2017). Metodychni aspekty rozvytku kreatyvnosti molodshykh shkolyariv na urokakh informatyky za dopomohoyu elektronno-osvitnikh resursiv [Methodical aspects of the development of creativity of junior schoolchildren in computer science lessons with the help of electronic educational resources]. "Youth and market". Monthly scientificpedagogical journal. Drogobych, Vol. 10 (153), pp. 28-34. [in Ukrainian].

Стаття надійшла до редакції 12.06.2020

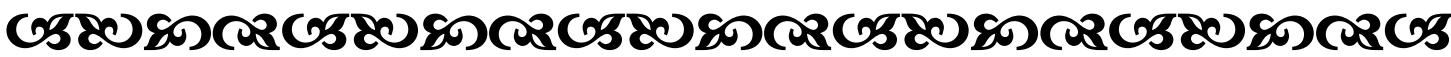

